\title{
Anticancer therapies in specialized palliative care-a multicenter survey
}

\author{
B. Alt-Epping • S. Pache • G. Lindena $•$ F. Nauck • \\ On behalf of the German Hospice and Palliative Care \\ Evaluation (HOPE) Working Group
}

Received: 25 May 2011 / Accepted: 5 December 2011 /Published online: 24 December 2011

(C) The Author(s) 2011. This article is published with open access at Springerlink.com

\begin{abstract}
Introduction Anticancer therapies gain increasing attention and discussion in specialized palliative care institutions. Frequency, indication, attitude of team members, and modes of these therapies implemented in specialized palliative care settings are still under investigation.

Methods Descriptive analysis of the nationwide Hospice and Palliative Care Evaluation 2007 that collected data from palliative medicine, hospice care, and oncology institutions concerning the use of anticancer therapies.

Results Three thousand one hundred eighty-four patients from 67 palliative care units, eight oncology wards, and other in- and outpatient institutions were registered. Two hundred eleven therapeutic interventions, mostly i.v. chemotherapy (28.9\%), have been documented in all institutions except from inpatient hospices. Although all institutions were asked to keep records from "palliative patients", those patients treated in oncology services differed from patients on palliative care units with respect to prognosis, therapeutic intention (symptom control versus tumor remission), and team attitude.

Discussion Anticancer therapies are incorporated into palliative care concepts. The described differences in palliative patients that are treated in specialized palliative care as compared to oncology services will have to be discussed
\end{abstract}

B. Alt-Epping $\cdot$ S. Pache $\cdot$ G. Lindena $\cdot$ F. Nauck

Department of Palliative Medicine, University Medical Center,

Robert Koch Strasse 40,

37075 Göttingen, Germany

G. Lindena

Institute for Clinical Research and Application,

Kleinmachnow, Germany

B. Alt-Epping $(\square)$

Abteilung Palliativmedizin, Universitätsmedizin Göttingen,

Robert Koch Strasse 40,

37075 Göttingen, Germany

e-mail: bernd.alt-epping@med.uni-goettingen.de with regard to selection of patients for specialized palliative care and the range of suitable treatment modalities in palliative care concepts.

Keywords Anticancer therapy $\cdot$ Palliative patient $\cdot$ Symptom control $\cdot$ Early integration

\section{Introduction}

Anticancer therapies (ACT) gain increasing attention in specialized palliative care institutions, where patients with incurable, far advanced, and progressive disease are treated, aiming a best possible quality of life. This expanded use of ACT follows recent paradigmatic developments in modern oncology, following approval of a broad number of new mainly non-cytotoxic substances (e.g., tyrosine kinase inhibitors (TKI), monoclonal antibodies, or immunomodulatory drugs/IMiDs). Furthermore, application schemes shift from cyclic intervals to continuous metronomic or maintenance application, leading to prolonged periods of continuing ACT during the course of the disease and a reduced time span between termination of specific ACT and death [6]. Therapeutic aims in oncology are increasingly focusing on clinical and subjective parameters, as reflected by new terms like 'clinical benefit response', 'time to progression', or 'time to deterioration of symptoms', instead on metric response parameters only, that are described by conventional oncological success criteria like 'partial/complete remission', 'stable disease', or 'disease progression'.

These redefined therapeutic goals of ACT owe tribute to the effects of ACT on symptom control that have been increasingly documented. In 1995 for example, effects of chemotherapy on dyspnea or cough were found in patients with small cell and non-small cell lung cancer [7] and confirmed in multiple studies (e.g., [12]). Similarly, a reduction in pain intensity was documented for the use of gemcitabine for patients with pancreatic cancer [3] or for the use of prednisone in combination 
with mitoxantrone or docetaxel, respectively [2], independent of additional effects on tumor load.

For all these reasons, it can be assumed that ACT are increasingly used in specialized palliative care institutions.

It is unknown, though, to what extent specialized palliative care institutions are in fact integrating ACT into their care concept, and if this intends to reinforce genuine palliative purposes like symptom control. Furthermore, the uniquely complex balance between clinical benefit and therapyassociated toxicity in a palliative care patient population, the preceding decision process for the integration of ACT in palliative care, the attitudes of team members towards this integration, the overall clinical outcome on symptom burden and quality of life, psychosocial co-factors, and the aspects that confound termination of ACT still need to be investigated.

\section{Methods}

The Hospice and Palliative Care Evaluation is a prospective, annual, nationwide multicenter survey period that collects data from different German-speaking institutions that treat in- and outpatients from a palliative care perspective. Since 1999, this documentation project has gathered data from 21,720 palliative patients (https://www.hope-clara.de/download/HOPE2011Kurzinformation.pdf; accessed 25.08.2011) that were treated at palliative care units (PCU), inpatient hospices (IH), oncology wards (OW), general practitioners, and oncology specialists (P\&S), and palliative 'home care' teams. Each participating institution is supposed to survey 30 consecutive patients in a 3month period, after written informed consent $[4,9]$. This annual survey has already gathered broad general and specific clinical information on age, diagnoses, symptom burden, therapeutic measures, or outcomes of patients in German palliative care and hospice institutions [15].

For the study presented here, the 2007 survey (15 March 2007 to 15 June 2007) was added an additional modular questionnaire (Fig. 1) that documented the clinical and conceptual aspects of ACT in palliative care, including the Palliative Prognostic Index (PPI) as a validated prognostic score [11].

As this explorative, descriptive study focused on reporting current practices with regard to ACT in palliative care and hospice settings, also including multiple answer questions, statistical analysis used predominantly descriptive tools and chi square testing but deliberately avoided multiple significance testing and its implicit errors.

The study was approved by the local ethics authorities.

\section{Results}

The 2007 Hospice and Palliative Care Evaluation (HOPE) surveyed 3,184 palliative care patients. The majority of the
149 contributing institutions were specialized palliative care units (67), which reflected a $47.2 \%$ survey participation of all German PCU. Furthermore, 28 practitioner and specialist practices (P\&S), 22 home care teams, eight oncology wards, and 24 inpatient hospices took part (in Germany, IH are referred to as institutions clearly focusing on nursing and psychosocial needs, supported by hospice volunteers, while medical surveillance and treatment is usually delivered there by competent general practitioners).

Four hundred sixty-seven modular ACT questionnaires were returned from 38 institutions (representing 14.7\% of all documented patients). In this cohort, 205 patients were documented to have received any kind of ACT during the observational period (247 therapeutic interventions).

As much as $6.4 \%$ of the total HOPE population was documented to have received ACT in one form or the other. Interestingly, all types of institutions were involved in documenting ACT, except from inpatient hospices. The ACT subgroup is characterized by a better ECOG score $(0-4$; [13]) fewer severely diseased patients (ECOG 3-4) and a lower likelihood of death during the observational period (Table 1). The majority of patients in the ACT subgroup suffered from gastrointestinal cancer (ICD-10 C15-C26; 27.0\%), followed by lung cancer (ICD-10 C30-C39; 14.8\%). Compared with results from other studies $[10,15]$, more women than men were registered. This difference in gender distribution was even more prominent in the ACT subgroup. Age distribution in the ACT subgroup was comparable to the general HOPE population (Table 1).

The relative number of patients who deceased during the observational period seemed to be lower in the ACT subgroup, as compared to the HOPE population. Also on specialized PCU, the relative number of ACT patients who died within the survey $(16.2 \%)$ was shown to be smaller than within the total HOPE cohort (32.8\%), but higher than on oncology wards (11.8\%, despite small absolute figures).

The majority of documented ACT referred to newly initiated therapies in palliative care services within the survey period (120 therapeutic interventions), as compared to 91 therapeutic measures described as continuing interventions throughout the survey period. The indication to apply ACT on a palliative care unit was defined by the pretreating department (and not by palliative care physicians themselves) in $48.6 \%$ of all ACT cases.

In $28.9 \%$ of the ACT subgroup, tumor therapy implied i.v. cytotoxic chemotherapy, but several other modes of ACT were used (Table 2). Chemotherapy and hormonal therapy was newly initiated or continued to roughly equal parts, while local procedures like radiation therapy or endoscopic interventions were predominantly newly initiated.

On PCU, anticancer therapies were mainly indicated for symptom control reasons (38.8\%), as compared to intended tumor regression (24.0\%). But even on OW, $28.6 \%$ of all ACT were initiated for symptom control reasons, as compared to $38.1 \%$ of all ACT intended for tumor regression. Pain was the 
Fig. 1 Hospice and Palliative Care Evaluation: $\mathrm{ACT}$ questionnaire
HOPE @2007 Tumorspezifische Therapien in d. Palliativmedizin

TT Basisbogennr.:

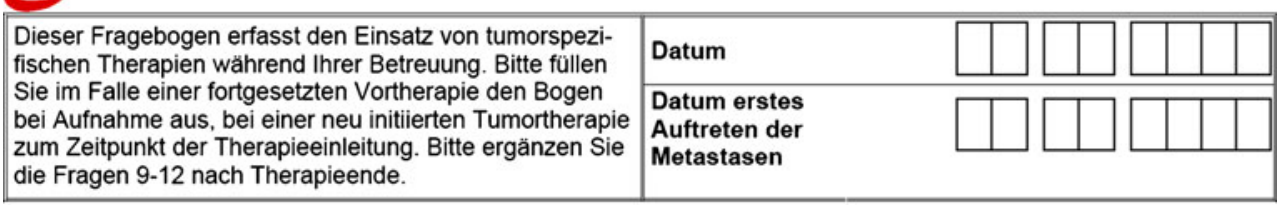

\begin{tabular}{|c|c|c|c|}
\hline TT1. Therapieform: & \multicolumn{3}{|c|}{$\begin{array}{l}\text { Fortgesetzt: Fortsetzung einer vorbestehenden Therapie } \\
\text { Neu: neu initiierte Therapie }\end{array}$} \\
\hline \multirow{2}{*}{\multicolumn{2}{|c|}{$\begin{array}{l}\text { intravenöse, zyklische oder kontinuierliche zytotoxische Chemotherapie } \\
\text { per orale, zyklische oder kontinuierliche zytotoxische Chemotherapie }\end{array}$}} & $\square$ fortgesetzt & $\square$ neu \\
\hline & & $\square$ fortgesetzt & $\square$ neu \\
\hline \multicolumn{2}{|c|}{ Tumorspezifischer Antikörper } & $\square$ fortgesetzt & $\square$ neu \\
\hline \multicolumn{2}{|c|}{ Hormontherapie } & $\square$ fortgesetzt & $\square$ neu \\
\hline \multicolumn{2}{|c|}{ per orale Tyrosinkinasehemmer oder andere „targeted therapy" } & $\square$ fortgesetzt & $\square$ neu \\
\hline \multicolumn{2}{|c|}{ Strahlentherapie } & $\square$ fortgesetzt & $\square$ neu \\
\hline \multicolumn{2}{|l|}{ Endoskopische Intervention } & $\square$ fortgesetzt & $\square$ neu \\
\hline \multicolumn{2}{|l|}{ Nuklearmedizinische Therapie } & $\square$ fortgesetzt & $\square$ neu \\
\hline \multicolumn{2}{|l|}{ Operative Intervention } & $\square$ fortgesetzt & $\square$ neu \\
\hline \multicolumn{2}{|l|}{ Andere Verfahren (bitte spezifizieren): } & $\square$ fortgesetzt & $\square$ neu \\
\hline \multicolumn{2}{|l|}{ TT2. Anzahl der Vortherapien: } & Chemotherapie & Hormontherapie \\
\hline \multicolumn{4}{|c|}{$\begin{array}{l}\text { TT3. Indikationen: } \\
\square \text { Tumorgrößenreduktion zur präventiven Symptomvermeidung und / oder Lebenszeitverlängerung } \\
\square \text { Vorwiegend zur Symptomkontrolle: }\end{array}$} \\
\hline $\begin{array}{l}\square \text { Neurologische Kompression + Hirndruck } \\
\square \text { Gastrointestinale Kompression }\end{array}$ & $\begin{array}{l}\square \text { Schmerzen } \\
\square \text { Sonstige: }\end{array}$ & $\square$ Luftnot & \\
\hline \multicolumn{4}{|l|}{ TT4. Substanzen / Regime / Modus: } \\
\hline \multicolumn{4}{|l|}{ TT5. Indikationsstellung durch: } \\
\hline \multicolumn{4}{|c|}{$\square$ Eigene Indikationsstellung nach Rücksprache mit anderen Fachdisziplinen } \\
\hline \multicolumn{4}{|c|}{ Eigene Indikationsstellung } \\
\hline \multicolumn{4}{|c|}{ TT6. Palliative Prognostic Index PPI unter der Vortherapie / zu Beginn einer neu initiierten Tumortherapie: } \\
\hline Palliat.Perform.Score $\square 4,0$ P (1PPS 0-20) & $\square 2,5$ P (PPS 20-50) & $\square$ OP (PPS $>60)$ & \multirow[t]{5}{*}{ PPI-Score: } \\
\hline$\square 2,5 \mathrm{P}$ (stark reduziert) & $\square 1,0 \mathrm{P}$ (moderat reduziert) & $\square O P$ (normal) & \\
\hline$\square 1,0 \mathrm{P}$ (ja) & & $\square \mathrm{OP}$ (nein) & \\
\hline Ruhedyspnoe & & $\square O P$ (nein) & \\
\hline Delirium $\quad \square 4,0 \mathrm{P}(\mathrm{ja})$ & & $\square O P$ (nein) & \\
\hline \multicolumn{4}{|c|}{ TT7. Bestand im Palliativteam Konsens über Fortsetzung / Einleitung der Tumortherapie? } \\
\hline \multicolumn{2}{|c|}{$\square$ Klarer Dissens; schwierige Entscheidungsfindung } & Gründe: & \\
\hline \multicolumn{2}{|l|}{$\square$ Eher Konsens, aber auch Stimmen dagegen } & & \\
\hline \multicolumn{2}{|l|}{$\square$ Klarer Konsens } & & \\
\hline
\end{tabular}

Bei Beendigung der Tumortherapie

TT8. Mit welchem subjektivem Erfolg wurde die Tumortherapie durchgeführt?

$\square$ sehr schlecht $\square$ schlecht $\quad \square$ zufriedenstellend $\quad \square$ gut

TT10. Wenn ja, welche Gründe lagen für den vorzeitigen Abbruch vor?

$\square$ Toxizitäten

$\square \mathrm{Ja}$

$\square$ Ineffizienz der Therapie

$\square$ Verschlechterung des Allgemeinzustandes

$\square$ Wunsch des Patienten

TT11. Bestand im Palliativteam Konsens über Abbruch / Beendigung der Tumortherapie?

प Klarer Dissens; schwierige Entscheidungsfindung Gründe:

$\square$ Eher Konsens, aber auch Stimmen dagegen

$\square$ Klarer Konsens

TT12. Wer füllt aus?

$\square$ Arzt / Ärztin Fachrichtung $\quad \square$ Innere Medizin $\quad \square$ Anästhesie

$\square$ Pflegende $\square$ Hämatologie/Onkologie $\square$ Sonstige: most often named indication for initiating ACT for symptom control (as reported in 60 cases), followed by dyspnea and neurological compression (Table 3). Institutional teams showed a high level of agreement towards treatment decisions; only $5.6 \%$ dissensual decisions were documented, almost exclusively in context with ACT intended for symptom control.

The modular ACT questionnaire also addressed prognostication of survival, using the Palliative Prognostic
Index and related this to ACT treatment decisions. In general, a PPI score indicating a better clinical prognosis was associated with a higher likelihood of receiving ACT, but nine patients received a newly initiated ACT despite a PPI $=2$ (that equals $20 \%$ estimated 3 weeks survival).

Indications to withhold or withdraw further ACT application comprised predominantly a deterioration of physical/ 
Table 1 Demographic characteristics

\begin{tabular}{lll}
\hline & $\begin{array}{l}\text { ACT subgroup } \\
(n=205)\end{array}$ & $\begin{array}{l}\text { HOPE cohort } \\
(n=3,184)\end{array}$ \\
\hline Mean age & $\begin{array}{c}66.7 \text { years } \\
\text { (SD 11.7) }\end{array}$ & $\begin{array}{c}67.7 \text { years } \\
\text { (SD 12.8) }\end{array}$ \\
Median age & 68.1 years & 68.9 years \\
Gender distribution & & \\
Male & $37.6 \%$ & $47.5 \%$ \\
Female & $62.4 \%$ & $52.5 \%$ \\
Death during survey period & & \\
Total & $12.4 \%$ & $31.1 \%$ \\
Palliative care unit & $16.2 \%$ & $32.8 \%$ \\
Oncology ward & $11.8 \%$ & $12.6 \%$ \\
Mean ECOG score on admission & $2.3(\mathrm{SD} 1.2)$ & $3.0(\mathrm{SD} 1.0)$ \\
ECOG 3-4 on admission $(\%)$ & $45.4 \%$ & $72.6 \%$ \\
\hline
\end{tabular}

functional state (48\%), as opposed to therapeutic ineffectiveness $(24 \%)$ or therapy related toxicities (in only $11 \%$ ).

From all documented ACT, 93 ACT were terminated within the observational period, mostly when tumor control was the underlying indication $(53.8 \%)$ as compared to an intended symptom control (18.3\%).

Team consensus in deciding to withdraw ACT was uniformly high. The carers were finally asked for a subjective overall assessment of application and outcome of a given ACT. On a scale from 1 (excellent) to 6 (fail), the average assessment was 2.7; but participation to this grading was particularly low (33.6\% response rate).

\section{Discussion}

This study describes anticancer treatment decisions at the interface between oncology and palliative care, and provides insight

Table 2 Modes of anticancer therapy (frequency of reports in absolute numbers; multiple answers permitted)

\begin{tabular}{lrrr}
\hline ACT: & Initiated & Continued & Total \\
\hline Intravenous cytotoxic chemotherapy & 61 & 48 & 108 \\
Oral cytotoxic chemotherapy & 10 & 13 & 23 \\
Tumor-specific antibody & 3 & 4 & 7 \\
Hormonal therapy & 10 & 19 & 29 \\
Oral targeted therapy & 2 & 5 & 7 \\
Radiation therapy & 33 & 10 & 43 \\
Endoscopic intervention & 10 & 1 & 11 \\
Radioisotope therapy & 0 & 0 & 0 \\
Surgical intervention & 8 & 0 & 8 \\
Other procedure or intervention & 9 & 2 & 11 \\
Total & 146 & 101 & 247 \\
\hline
\end{tabular}

Table 3 Symptoms leading to ACT (frequency of reports in absolute numbers; multiple answers permitted)

\begin{tabular}{lrrrrr}
\hline & Total & PS & OS & AA & AP \\
\hline Pain & 60 & 49 & 6 & 2 & 3 \\
Dyspnea & 26 & 19 & 3 & 2 & 2 \\
Neurological compression & 20 & 17 & 3 & 0 & 0 \\
Gastrointestinal compression & 13 & 12 & 0 & 1 & 0 \\
Others & 6 & 5 & 0 & 0 & 1 \\
n.a. & 29 & 26 & 3 & 0 & 0 \\
Total & 131 & 109 & 12 & 4 & 6 \\
\hline
\end{tabular}

into a group of severely and incurably ill cancer patients that are treated in different institutions from a palliative care perspective.

The study shows that ACT is an infrequent but quite relevant part within the treatment spectrum in palliative care institutions in Germany, except from inpatient hospices. Most often, conventional chemotherapy was used, while targeted therapies with their putatively smooth way of application were seldomly selected. Also surprising, even under the premises of palliative care, some of the included patients have received ACT until the very late stages of their disease, despite a very poor overall prognosis, as measured by PPI. The use of ACT for patients that died within the next 2 weeks (which is generally being considered an indicator of poor quality of care; $[5,6])$, is therefore not only a problem for oncology, but also for specialized palliative care institutions.

The Hospice and Palliative Care Evaluation implies that all participating institutions propose those patients for inclusion that are considered as "palliative patients". Therefore, it is not self-evident at all that patients under oncological surveillance as compared to specialized palliative care institutions showed distinguishing features in terms of surviving the observational period, preceding functional state, team attitude, and the intended therapeutic goal of a given ACT. This finding might imply (despite small absolute figures) procedural, conceptual, and definitional differences of palliative care between oncology and palliative care institutions; a "palliative patient" in the PCU seems to differ from a "palliative patient" in oncology institutions. On the other hand, conscientiously differentiating which patient might still qualify for ACT might also reflect a feature of "individualized care" [14]: "Anticancer therapy should be discussed and offered when evidence supports a reasonable chance of providing meaningful clinical benefit." Therefore, these results also underline the need for interdisciplinary collaboration.

This study faces several limitations: The lack of a clear cut definition of inclusion criteria denotes a major problem of the Hospice and Palliative Care Evaluation in general; the term "palliative patient" is neither defined nor operationalized there. This methodological problem leads over to the general 
discussion which patient is eligible for specialized palliative care. This immanent problem is even more fuelled by recent studies that propagate early integration of palliative care into oncological treatment concepts [16]. This development of "early integration" might certainly contribute to care concepts where anticancer therapy (aiming at tumor regression, prolonging life, or improvement of symptoms) and symptomguided palliative care will be applied simultaneously or where palliative care is being incorporated into cancer care [8].

Other limitations of this study relate to data quantity and methodology: The poor return of the ACT questionnaires prevents generalizability and does not allow conclusions about absolute prevalences of ACT in palliative care institutions. Input from oncology wards was especially sparse, although it can be postulated that a great number of patients fulfilling palliative eligibility criteria are treated in oncology institutions. In detail, 50 of those 262 questionnaires that did not describe ACT during the observational period suggested previous ACT but left open when ACT had been terminated (long before or during the observational period), and had therefore to be excluded from analysis. The use of the Palliative Prognostic Index [11] might have led to irritation and misunderstandings, as it comprises several items including the Palliative Performance Score [1], which denotes a modified Karnofsky Performance Score. Some other questionnaire items like the subjective overall assessment of application and outcome were characterized by hesitant response. The need for informed consent might have lead to a general bias in the Hospice and Palliative Care Evaluation, as it has to be postulated that an undetermined number of patients will not have been able to complete the consent process in the respective palliative care or hospice settings. Finally, as the purpose of this survey was to describe current practices on ACT in palliative care and to generate hypotheses for further study at the interface of palliative care and oncology, we deliberately avoided significance testing, in order to prevent multiple testing errors.

In conclusion, this study shows that the use of ACT refers to a distinguishable subgroup of palliative care patients in distinct institutions and is therefore more than a mere expansion of the therapeutic (pharmacologic) spectrum in palliative care. The continuing debate about integrating ACT into palliative care concepts and about early integration of palliative care into oncology has now gained new arguments.

\section{Conflict of interest The authors declare there is no conflict of interest.}

Open Access This article is distributed under the terms of the Creative Commons Attribution Noncommercial License which permits any noncommercial use, distribution, and reproduction in any medium, provided the original author(s) and source are credited.

\section{References}

1. Anderson F, Downing GM, Hill J, Carsorso L, Lerch N (1996) Palliative performance scale (PPS): a new tool. J Palliat Care 12(1):5-11

2. Berry DL, Moinpour CM, Jiang CS, Ankerst DP et al (2006) Quality of life and pain in advanced stage prostate cancer: results of a Southwest Oncology Group randomized trial comparing docetaxel and estramustine to mitoxantrone and prednisone. J Clin Oncol 24(18):2828-2835

3. Burris HA 3rd, Moore MJ, Andersen J, Green MR, Rothenberg ML, Modiano MR, Cripps MC, Portenoy RK, Storniolo AM, Tarassoff P, Nelson R, Dorr FA, Stephens CD, Von Hoff DD (1997) Improvements in survival and clinical benefit with gemcitabine as first-line therapy for patients with advanced pancreas cancer: a randomized trial. J Clin Oncol 15:2403-2413

4. Determann MM, Rzehak P, Küchler T, Dzeyk W, Fuchs M, Kemna G, Neuwöhner K, Passon M, Radbruch L, Lindena G, Finnern J (2000) Qualitätssicherung in der Palliativmedizin. Forum Deutsche Krebsgesellschaft 15:10-13

5. Earle CC, Neville BA, Landrum MB, Ayanian JZ, Block SD, Weeks JC (2004) Trends in the aggressiveness of cancer care near the end of life. J Clin Oncol 22:315-321

6. Earle CC, Landrum MB, Souza JM, Neville BA, Weeks JC, Ayanian JZ (2008) Aggressiveness of cancer near the end of life: is it a qualityof-care issue? J Clin Oncol 26:3860-3866

7. Ellis PA, Smith IE, Hardy JR, Nicolson MC, Talbot DC, Ashley SE, Priest K (1995) Symptom relief with MVP chemotherapy in advanced non-small cell lung cancer. Br J Cancer 71(2):366-370

8. Ferris FD, Bruera E, Cherny N, Cummings C, Currow D, Dudgeon D, JanJan N, Strasser F, von Gunten CF, Von Roenn JH (2009) Palliative cancer care a decade later: accomplishments, the need, next steps - from the American Society of Clinical Oncology. J Clin Oncol 27:3052-3058

9. Lindena G, Nauck F, Bausewein C, Neuwöhner K, Heine O, Schulenberg D, Radbruch L (2005) Qualitätssicherung in der Palliativmedizin - Ergebnisse der Kerndokumentation 1999-2002. Z Ärztl Fortbild Qual Gesundhwes 99:555-565

10. Lövgren M, Tishelman C, Sprangers M, Koyi H, Hamberg K (2008) Symptoms and problems with functioning among women and men with inoperable lung cancer-a longitudinal study. Lung Cancer 60(1):113-124

11. Morita T, Tsunoda J, Inoue S, Chihara S (1999) The Palliative Prognostic Index: a scoring system for survival prediction of terminally ill cancer patients. Support Care Cancer 7:128-133

12. O'Brien M, Ciuleanu TE, Tsekov H, Shparyk Y, Cucevia B, Juhasz G, Thatcher N, Ross GA, Dane GC, Crofts T (2006) Phase III trial comparing supportive care alone with supportive care with oral topotecan in patients with relapsed small cell lung cancer. J Clin Oncol 24(34):5441-5447

13. Oken MM, Creech RH, Tormey DC, Davis TE, McFadden ET, Carbone PP (1982) Toxicity and response criteria of the Eastern Cooperative Oncology Group. J Clin Oncol 5(6):649-655

14. Peppercorn JM, Smith TJ, Helft PR, DeBono DJ, Berry SR, Wollins DS, Hayes DM, Von Roenn JH, Schnipper LE (2011) American Society of Clinical Oncology statement: toward individualized care for patients with advanced cancer. J Clin Oncol 29:755-760

15. Radbruch L, Nauck F, Fuchs M, Neuwöhner K, Schulenberg D, Lindena G (2003) What is palliative care in Germany? Results from a representative survey. J Pain Symptom Manage 23(6):471-483

16. Temel J, Greer JA, Muzikansky A, Gallagher ER, Admane S, Jackson VA, Dahlin CM, Blinderman CD, Jacobsen J, Pirl WF, Billings JA, Lynch TJ (2010) Early palliative care for patients with metastatic non-small cell lung cancer. N Eng J Med 363(8):733-742 